「風合い」特集

\title{
“風 合い”の検索システム
}

原田隆司・斎藤実

\section{1. はじめに}

風合いは, テキスタイルの最も重要な特性の1つであ ク, 生産および販売の現場で日常的に話題の対象とされ る。しかしながら風合いは感覚としてとらえられるもの で, それを表現する言葉の内容は人によってもテキスタ イルの種類によっても異なりあいまいな面が少なくな く, 風合いに関する要求と提供品とのミスマッチがしば しば発生する。

風合い検索システム「HIPS」(Handle Information \& Planning System)は,コンピュータを使い希望する風合 いのテキスタイルを素早く見付け出す検索システムであ る。「っとこしがほしい」「もう少しソフトな生地」な どのあいまいな表現を物性值に変換してデータベースの 中から最適なサンプル生地を探すもので，人手で探す作 業を軽減でき, 顧客の風合いに関する注文が確実に把握 できるようになった。本システムは本店 (大阪)の展示商 談室テキスフォーラムに設置し，まず毛織物について実 用化(1987年11月新聞発表), 生産現場(三重工場) とも才 ンラインで結んでいる。今後順次対象とするテキスタイ ルを拡大していく予定である。

風合いの計測に関して東洋紡は永年研究を行ってきて $お \eta^{1.14-17)}(1972$ 年繊維機械学会論文賞受賞) 先駆的役 割をはたしてきたが，この基礎的な研究を基盤として現 場における風合いに関する問題に対処するために本シス テムを開発したのである。

ここでは，風合いをどのようにとらえるのかについて 考え方をまず述べ, 次に風合い検索システム「HIPS」 の内容を紹介する。

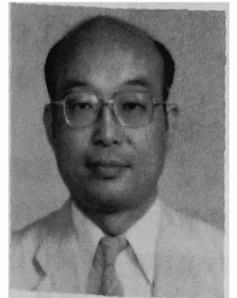

原田 隆司氏

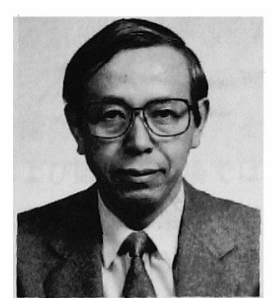

斎藤実氏
Handle Information \& Planning System

筆者紹介 TAKASHI HARADA

Corporate R \& D Division, Toyobo Co. Ltd.

東洋紡績株式会社 研究総括部主幹 学術博士

MINORU SAITOH

Research Institute, Toyobo Co. Ltd.

東洋紡績株式会社 棇合研究所 主席部貝

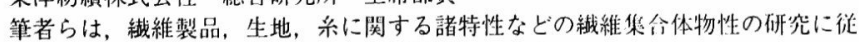
事され，䄉維機械学会論文賞などを受賞されている。

本稿では，風合いをどのように捉えるかについての考えう，ささらに風合い検奖 システム「HIPS」について紹介していただいた。 


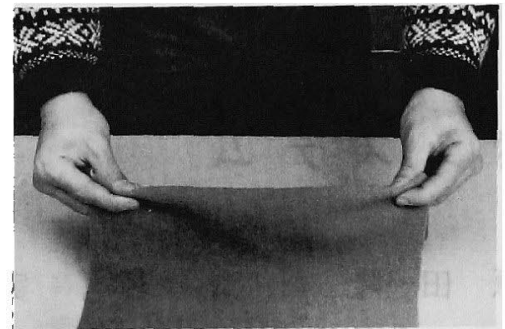

タイプ $A_{1}$

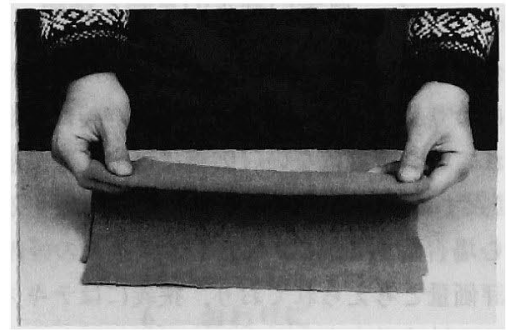

タイプ $A_{3}$

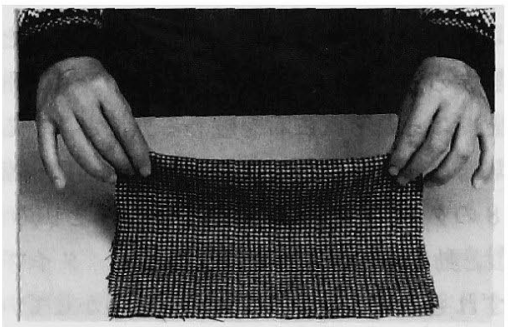

タイプ

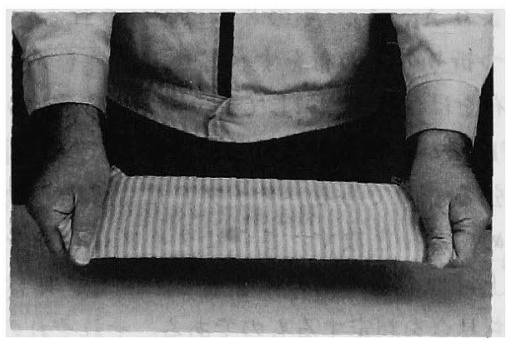

タイプE

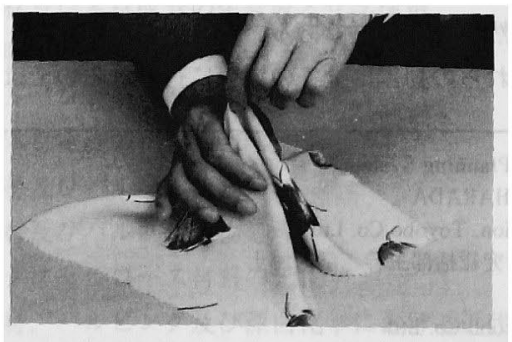

タイプ G

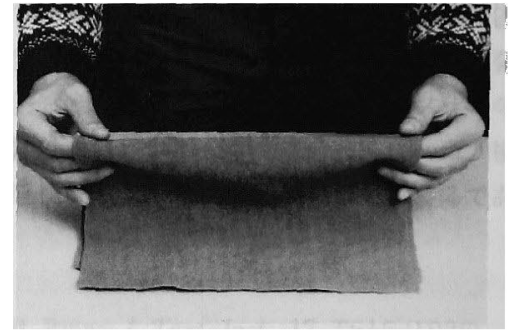

タイプ $\mathrm{A}_{2}$

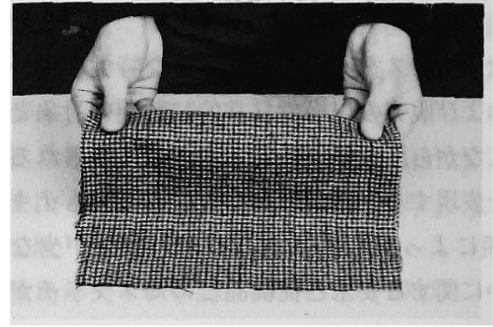

タイプ B

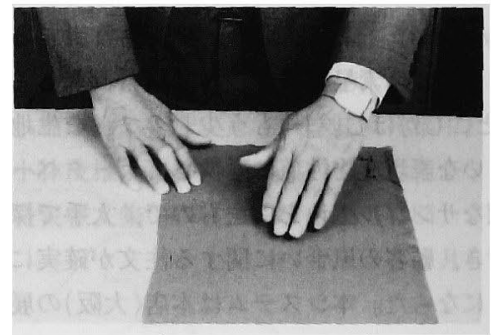

タイプ D

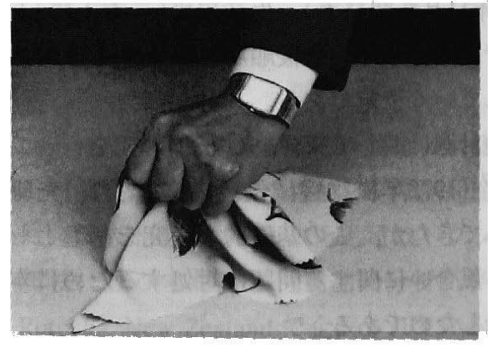

タイプ F

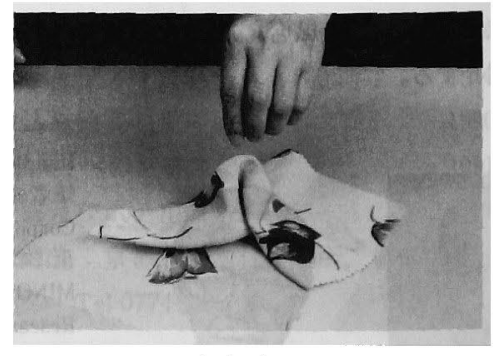

タイフ H

図 1 風合い判定時の動作 
対象となるテキスタイルの種類によって異なる。毛織物 の場合は，布を2つ折りにした状態で様々な変形を与え るタイブ A，B，Cが用いられる。フィラメント織物の 場合は手のひら全体で握りそして放す夕イプ $\mathrm{F}$ や，布 のすべりの状態をみるタイプA(2つ折り)，タイプD (布表面)拉よびタイプ $\mathrm{G}$ (指の環)が用いられる。さらに 布をつまんで持ち上げ落して布の立ち具合いをみる夕イ ブH も重要視されている。綿織物の場合は，手のひら 全体でにざるタイプ F，2つ折りの折り目を押さえる夕 イプC，さらに布をつまんで持ち上げ布の立ち具合いを みるタイプHが主に用いられる。ニットの場合は， 2 つ折りにしてすべらすタイプBが主に用いられ，布表 面をすべらすタイブD，2つ折りの中に指を入れるタイ ナ $\mathrm{A}_{2}$ ，手のひら全体で握りそして放すタイプ下や布を つまんで持ち上げ落し布の立ち具合いをみるタイプ $\mathrm{H}$, 布の引張りをみるタイブEも用いられる。

テキスタイルの種類(服種)ごとに，風合いを日常業務 としている専門家に1对比較法で風合いの違いを(触感 覚によるものに限る)をたずねた。尃門家の使う言葉に 汸好みを表現するもの(価値風合い)と風合いの特徴を表 現するもの(性格規定風合い)とがある。性格規定的に表 現する言葉を風合い形容語と呼ぶこととする。この風合 い形容語は非常に多く 1 服種のテキスタイル(例えば秋 冬物种士用毛織物)で50前後南る。同じ言葉が色々な服 理のテキスタイルに共通して用いられる場合もあり，風 合い形容語として130を越える言葉が使われている゙!。

風合いに関する研究は，Binns ${ }^{7}$ の官能検查に主体を

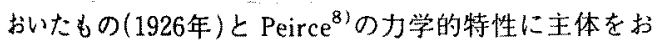
いたもの(1930年)に端を発している。その後さしたる進 展はなかったが，1950年以降数多くの論文が発表され 太。主な研究を紹介する。Hoffman ら 基本となる因子(13の因子)を抽出した(1951年)。 Howorth $5^{(0)}$ は風合いの官能特性感覚量と物性值の対 応関保を統計的手法により解析した(1958年)。さらに Brand ${ }^{11}$ はテキスタイルの美的特性を体系的に論じる中 で多数の風合い形容語間の関係について定性的な位真つ けをした(1964年)。Livesey ら ${ }^{12)}$ は曲げ変形装置を試作 しヒステリシス曲線として解析する計測法へと発展させ た(1964年)。これら1960年代までの風合いに関する研究 をまとめ解説したものが単行本として出版されてい $3^{(3)}$ 。

このように数多くの論文が発表され，それぞれの手法 岋進展したが、生産および販売の現場では使いにくいも のたった。その理由は次の 3 つに集約される。

1) 屈合い形容語の整理, 体系化が出来ていない。

風合いは感覚としてとらえられ，それを言葉(風合い
形容語)として表現されるが，その数は前述したように 極めて多い。この風合い形容語は微妙な表現の違いによ って使い分けられたり，同じ表現であっても股種によっ て又人によってその内容が異なる場合が多々ある。

多くの研究者は風合いに関して高度の訓練を受けたい わゆる羿門家のみが判定能力があるとして，一種の畏服 の感をもつ傾向があり，判定の内容を解析するという試 みはほとんど見あたらない。

風合いの内容を正確にしかも効率的に表現できるよう な風合い形容方法を確立する必要がある。

2) 計測される力学的特性が風合い(風合い形容語)とど のような関係があるのかが明確にされていない。

風合いと対応のありそうな複合的な力学的特性(例之 ばハンドルオメーター法, リング法)を㵋定する方法が 提案されているが，理論的根拠が不明である。特定の力 学的特性を測定することによって風合い計測を代行しよ うとする行き方が声るが，前述の風合い判定の動作から もわかるように単に特定の力学的特性のみを測定しても 風合いのある一面を測定したにすぎない。

風合い(風合い形容語)との関倸が明確な、機器計測を 基盤とした手法の確立が必要である。

3) 風合い(感覚量) と力学的特性 (物性値)との対応関係 を統計的手法により解析する手法は，その適用に限界が ある。

官能検查の手法で数量化された風合い官能量 $\mathrm{y}$ と力 学的特性 $\mathrm{xi}$ との関係について $\mathrm{y}=\mathrm{f}(\mathrm{xi})$ という式を一旦 求めておき，その後は力学的特性 xi を測定することに より風合い量 $\mathrm{y}$ を求めるという方法がある。このよう な風合いの物理的内容についてはブラックボックス的に 考え，尃ら統計的因果則のみに頼るという結果が允分な 普遍性を獾得するには，それに見合う数多くの適切なパ ネルと試料を必要とする。従って試料の多種性，パネル の多様性，前述した判定方法の多様性さらに130を越え る風合い形容語があることを考えると、この力法は限界 があると言わざるを得ない。事実個別に発生した風合い に関する課題が，それまでに統計的手法で得られた試料 やパネルの範囲にない場合がある。現場においてあまり 使われていないのが寒態であろう。

個別の問題に柔軟に対忍できることが必要である。

\section{3. 風合い計測法の基本的な考え方}

松尾 ${ }^{14)}$ が1970年に発表した風合い計測法は，前述し たそれまでの風合いに関する研究の課題を解決したもの といえる。筆者らはこの考えうのものに一連の研究を進 めている。

風合いを触感覚を中心とする感覚評価量と狄茂にとら 


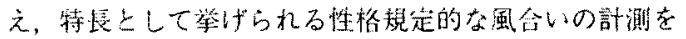
研究就秘とすることにする。

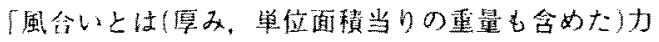
学的特性を手でもって官能的にとらえたものである」と いう作業仮説のもとに，図2に示方法で行う。

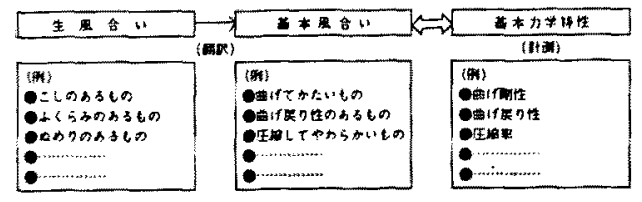

图 2 風合い棓十測方法

生風合いとは、日常使われてい石風合い形察語のこと て，前述した1300語葉がこれに相当する。

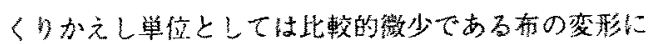
おいては，(1)曲げ変形，(2)伸長变形，(3)剪断变形，(4)压

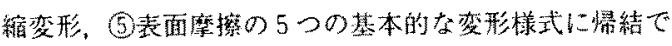
きるので、これに(6)覃み，(7)目付惊を加えて基本力学特 性としだ。

基本風合いとは基本的な力学的特性（基本力学特性）索 反瞋しな風合いに関連させた形容語であり表1に示す。

生風合いは，人るるいはデスタイルの種類によって もその内容が微妙に翼なるため，そのままでは基本力学

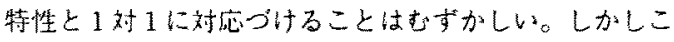
の日常使われている風合い形容語(生風合い)でも基本風

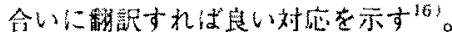

このような国合い計測の手法をとれば要求されるいか

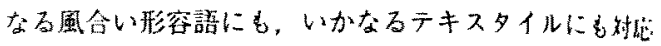
できる。

なお表 1 の力学的特性はKES-F 計測システム゙の標 準条件で測定する。

\section{4. 生風合いから基本風合いへの媩訳}

風合い計測のなかで生風合いから基本風合いへの制訳

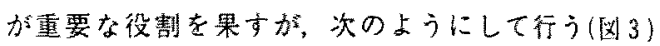
18. 19)。

翻訳者(インストラクタ)は翻訳辞典と顧客の風合い判

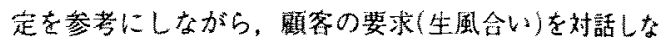
がら基本風合い经翻䛊する。例えば“ソフトである゙と

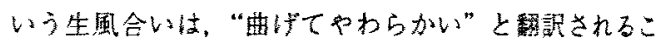
ともあれば，“死維してやわらかい”に翻訳されること
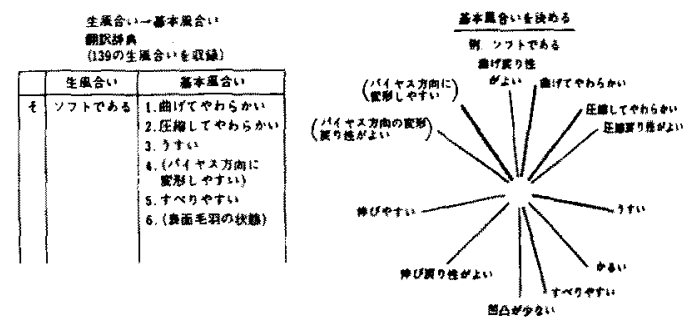

図3生風含いから基本風合いへの翻訳

表 1 基本風合いと基本力学特性との対応

\begin{tabular}{|c|c|c|c|}
\hline 基 本 風 合 & 対 応 特 & 性 & 基本力学特性 \\
\hline 曲げてゃわらかいい膰げてかたい & 曲结䁌推 B & $小 \leftrightarrow 大$ & \multirow{2}{*}{ 曲活染形 } \\
\hline 曲げ戻り性がよいい曲げ戻り性がわるい & 曲げ扈り性 $2 \mathrm{HB} / \mathrm{B}$ & 小セ大 & \\
\hline 伸びやすい伸びにくい & 引漲侮長率 EMT & 大セ小 & \multirow{2}{*}{ 伸表凌形 } \\
\hline 伸び戻り性がよいせ伸び底り性がわるい & 枵張回復率 RT & 大セ小 & \\
\hline \multirow{2}{*}{ 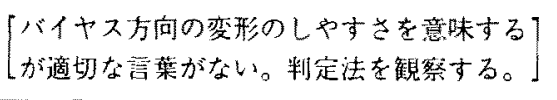 } & 真断岡性 $\mathrm{G}$ & & \multirow{2}{*}{ 新䉼変形 } \\
\hline & 禀断戻り性 $2 \mathrm{HG} / \mathrm{G}$ & & \\
\hline 生縮してやわらかいい厓維してかたい & I 穛 性 WC/T & 犬セ小 & \multirow{2}{*}{ 压液変形 } \\
\hline 压縮戻り性がよいい压縮荞り性がわるい & 縮回復率 RC & $大 \longleftrightarrow 小$ & \\
\hline すべりゃすいせすべりにくい & 摩擦你数 MIU & M七大 & \multirow{2}{*}{ 表媔繁擦 } \\
\hline 凹日が少ないせ凹凸が多い & 表面凹凸低数 SMD & 小њ大 & \\
\hline い山厚 & み $T$ & 小セ大 & 厚 \\
\hline$v: \leftrightarrow$ 重 & 目付 & 小心 & 目付 it \\
\hline 毛羽 & 毛羽我準 KBA & 小セ大 & \\
\hline
\end{tabular}

(注)表面毛羽の状態は基本風合いではないが，しばしば使われるので加えた。 毛羽水集は 3 段階で表示。 
もある。顧客が複数の生風合いで表現する場合がある。 このときでも生風合いをそれぞれ基本風合いに翻訳して 唋合してみればよい。基本風合いに翻訳されれば，対応 する基本力学特性は表1より自動的に選べる。

罱訳辞典は1390生風合いについてコンピュ夕に収録 されており，最初の文字を入力すると関連する部分の翻 訳辞典が CRT 画面に表示される。

風合い検索システムは，風合いに関する要求を言葉で 䦎き，その要求に合った風合いのテキスタイル見本を基 本力学特性値のデータベース加検索して顧客に提示す るものである。上で述べた方法で生風合いから基本風合 いに媩訳し，基本力学特性に变換しても，そのままでは 特性值のデータベースから検索することはできない。検 索するためには，検索すべき基本力学特性值とその範囲 を定めてやる必要がある。顧客に風合い要求を出しても らう際に，“もう少し”と加“とっという程度示 寸表現に着目して検索すべき基本力学特性の籁囲を決め る。このために升別閾(厚みは $5 \%$ ，他は $10 \%)^{15)}$ を参 考に基本力学特性ごとに基準となる值にどれだけ差をも たせれば良いかを設定している(図 4)。

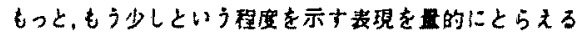

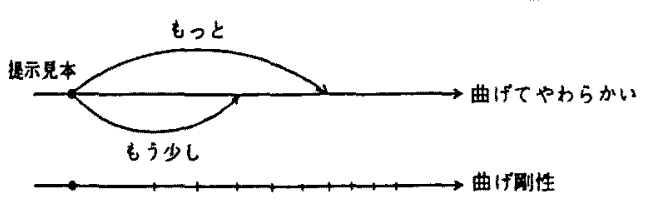

図4程度を示す表現の量的とらえ万

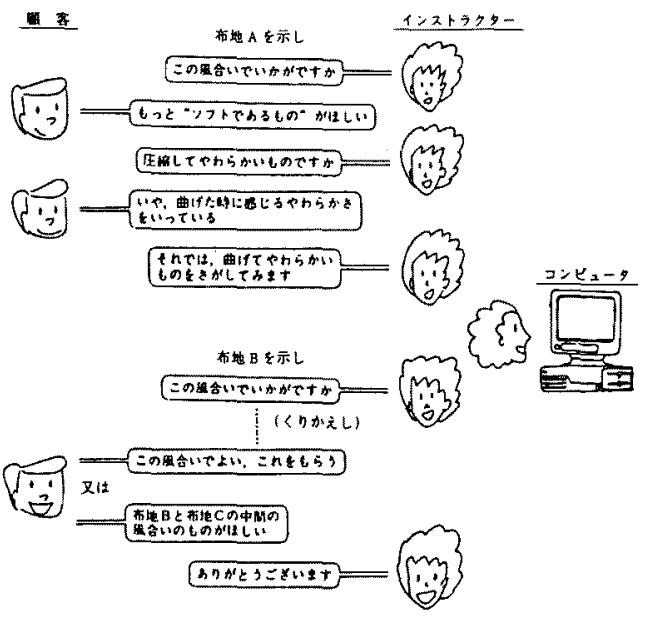

图 5 風合い検索手順(模式図)

\section{4. 検索システム}

本システムは，営業マンが䫏客に対応している姿を参 考に組立てた。その手順を模式的に図 5 に示す ${ }^{18.19) 。 ~}$

まず用途，素材，組織など一般的な要求を聞いて，該 当する見本を 2 - 3 点検索し提示する。その中加要求 に最も近いものを顧客に選んでもらい，それに対して風 合い要求を聞き基本風合いに翻訳し，基本力学特性扔よ び範囲を定如基本力学特性値のデータベース上り検索す る。検索された数点の見本を提示し，要求するものがあ るかどうかを尋ねる。もしも要求したものがなければ， 最も要求に近いものをべースにして翻訳，検索，提示を

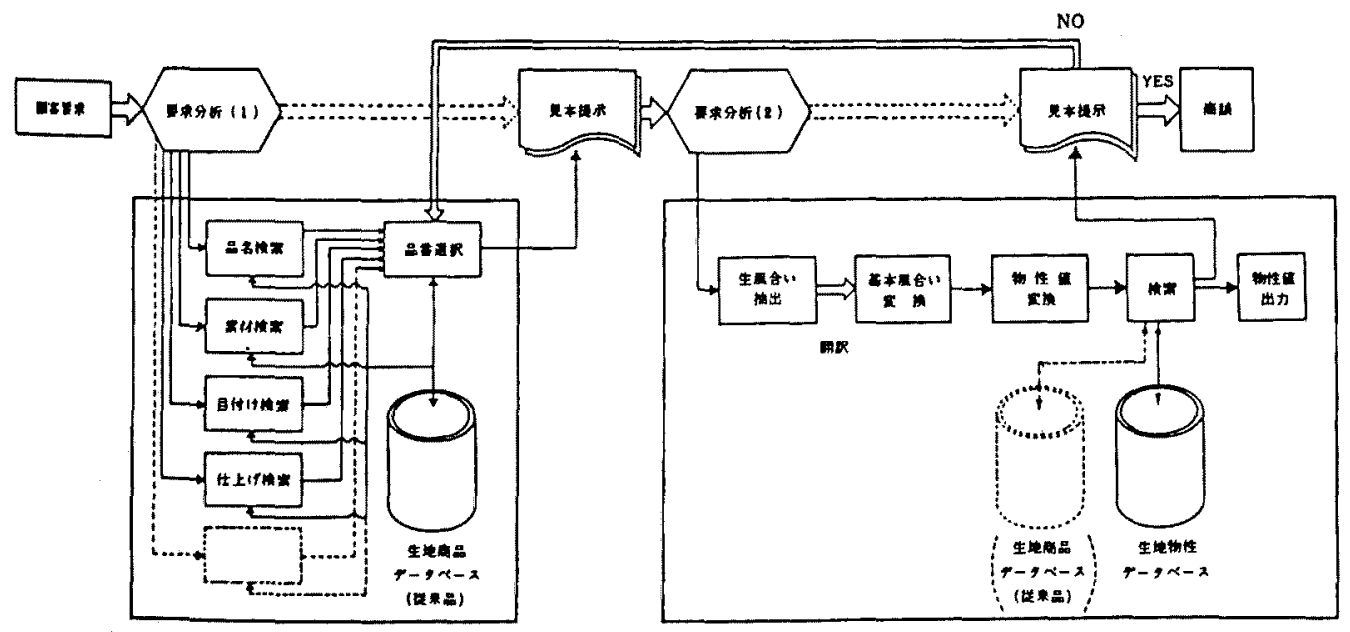

テキスフォーラム検索システム

風合い検索システム(新設)

図 6 風合い娭索システム算成図 
繰り返す。

これまての経験ではせいぜい2回も行えば艮い(所要 時间：5ー10分)。たたしテキスフォーラムに展示保管 しているものの中から検索するのであるから，碓客の旺 むものがずばり検萦されるとは限らず，近傍のものしが

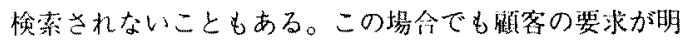
確にとらえられることになり，これまでしばしば発生し ていた惟客の装求と奏際に坐济したものとの風全いに関 するミスマッチが解消される。

本システムの模成の中で集材，維織，仕上方法に関す る检索システムは既に設苗されており。これに新たに風 合い検索に関連したシステムをドッキングしたもので， IBM「システム36SX」を使用している(図6)。本店(大 阪)のテキスフォーラムの各商談公抢よび生症現場であ る三重工場(四日市)にある端末機から検索できる。

\section{5. おわりに}

風合いは徒来10年，20年と年季のはいった撃門策しか 报えないとされてきた。本システムを使えば，風合いに 関しては素人でもテキスタイルに関心さえあれば1〜2 週間の訓練でインストラクタの䬭成は叮能である。

風命い恰索システムは, 生烧および販壳の現場で発生 する風合い红関する問題解汽に役立つとともに，生潼と 販売とを結びつけクィックデリバリーにも奇与できる。 思えば20年におよぶ基礎的な研究の蓄積とコンピュー夕 の進展があってはじめて出来たのである。

\section{文献}

1) 松尾：綫維と工業，5，291（1972）

2) 璟斗：䋘維と工業，5，299（1972）

3) 小林：繊機誌，26, P. 88 (1973)，37, P. 451 (1984)

4) 川端：擮譏誌，26，P.721（1973）

5 ) 牧鼠:織学誌, 36, P-123 (1980)

6 ) 斎藤, 原田；䄉機誌，40, P. 239 (1987)

7) H. Binns; J. Text. Inst. 17, T615 (1926)

8 ) F. T. Peirce: J. Text. Inst.. 21. T377(1930)

9) R. M. Hoffman, L. E. Beste; Tert. Res. J., 21, 66 (1951)

10) W. S. Howorth. P. H. Oliver; J. Text. Inst., 49, T540 (1958)

11) R. H. Brand: Text. Res. J.. 34, 791 (1964)

12) R. G. Livesey, J. D. Owen; J. Text. Inst. 55, T516 (1964)

13）繊機学会編，「布の風含い」，1972, 䋥譏学会

14) 松尾; 絨機誌, 23, T134 (1970)

15) 那須，斎藤，松尾；瀻穖誌，24，T58 (1971)

16）原田，斎藤，松尾；織機誌，T26（1971） 原田，松尾；「布の風合い」，P.61，1972, 线機学 会

17）松尾，原田，斎藤；䄉機誌，25，T9（1972）

18) 原田，斎藤；維機誌，41，P.305 (1988)

19）凨藤，堤，原田；䋐消誌，30，289（1989）

(平成元年 3 月 8 日受理)

\section{第13回 工業教育に関する講演会の講座募集}

1. 主 催：社团法人日本上業教育協会

2. 協 贊：䋐踓学会はか

3. 期 日：平成 2 年10月27日(土)

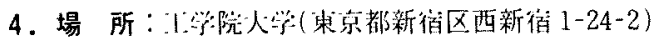

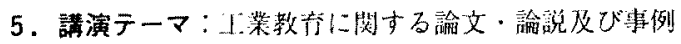
解出i

6. 講演者の資格：(社)日本工業教育協会及び各地区上

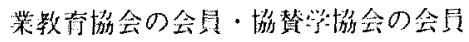

7、講演時問：1 題目につき講演15分，討議 5 分(予定)

8. 請演申込：締切平成 2 年 7 月31日(火)必着

9、䛾演予稿：9月10日(月)必着。

問い合わせ先 :

(社)日本工業教育協会 TEL 03-571-1720, 575-4236, FAX 03-289-0493 テ105 東京都港区新橋 2-19-10 藏前工業会館内（担当：原田・青山） 